\title{
Annual course of temperature and precipitation as proximal predictors of birds' responses to climatic changes on the species and community level
}

\author{
Olexander Koshelev, Vasiliy Koshelev, Marina Fedushko, Olexander Zhukov*
}

Bogdan Khmelnitsky Melitopol State Pedagogical University, Hetmanska st., 20, Melitopol, 72318, Ukraine

\begin{abstract}
Koshelev, O., Koshelev, V., Fedushro, M., Zhukov, O., 2021. Annual course of temperature and precipitation as proximal predictors of birds' responses to climate changes on the species and community level. Folia Oecologica, 48 (2): 118-135.

The study was conducted in the landscapes of south-eastern Ukraine during the nesting seasons 1988-2018. Within the landscape system associated with the Molochny Estuary, the ten most important ecosystem types were investigated, including the following: agricultural land, vegetated strips, meadows, islands and spits, reedbeds, urban areas, salt marshes, steppe, cliffs, artificial forests. Bird species responded to temperature and precipitation gradients. The patterns of responses were presented using Huisman, Olff and Fresco expanded by the Jansen-Oksanen hierarchical models. The nature of species response in the gradient of temperature or precipitation conditions depends on the type of particular ecosystem and is not uniform for all populations inhabiting the different landscape types. The bird communities were revealed to demonstrate an abrupt dynamic over time. The continuous changes in community structure initiated by the external environmental factors are combined with modifications of internal biotic interactions, which may lead to abrupt reorganization of the community.
\end{abstract}

Keywords

ecological niche, landscape diversity, ordination, temporal dynamic, trajectory analysis

\section{Introduction}

The climate affects a large number of major ecological mechanisms (WALTHER et al., 2009). Climate determines the structure of ecological systems at different hierarchical levels (Miller, 2008). At the local level, a directed community turnover may be observed due to changes in the environment (Dreslerová, 2017; FAHRIG, 2003; LEE et al., 2019). The role of climate gradients becomes crucial for communities on large spatial and temporal scales (Metz and Tielbörger, 2016; Mucina, 2019; PARMESAN, 2006). A disturbance of climatic regimes can lead to shifts in species ranges when temperatures rise (Grimm et al., 2013; Krosby et al., 2015). In the conditions of global warming, the geographical location of a species' climatic niche optimum changes, which affects the composition of communities in general (PAUTASSO, 2012; VelásQueZ-TiBATÁ et al., 2013). Thermophilization

\footnotetext{
*Corresponding author: e-mail: zhukov_dnipro@ukr.net 
of biological communities is considered as one of the main consequences of climate change (DE Frenne et al., 2013; PARmesan and Yohe, 2003). The influence of climate on bird community dynamics was estimated using the Community Temperature Index (CTI) (Bowler and Böhning-Gaese, 2017; Devictor et al., 2008). This index depends on the dominance of warm- and cold-dwelling species (Devictor et al., 2012). The species temperature index (STI) is designed to identify the temperature niche of a species and can be calculated using temperature within the species' distribution range (KAMPICHLER et al., 2012; Rотн et al., 2014). CTI is derived from the abundance of species and their STIs and thus is a measure of the average temperature niche in a community (DEVICTOR et al., 2012; GoDET et al., 2011).

The concept of an ecological niche allows us to give qualitative and quantitative characteristics of the influence of environmental factors on species (DEVICTOR et al., 2010; Zimaroeva et al., 2016). Application of Hutchinson's $n$-dimensional niche concept often focuses on the role of interspecific competition in the formation of species distribution models (Pulliam, 2000). The habitat and climate components of the ecological niche are considered as independent dimensions of species response to global ecological trends (BARNAGAUD et al., 2012). The distribution of species and their changes are usually explained and predicted using large-scale climate variables, with the local habitat being considered as a secondary detailed filter with limited prognostic power (Blinkova and Shupova, 2018; KorŇAn and Adamík, 2014; Oedekoven et al., 2017; Pearson and Dawson, 2003; Titeux et al., 2017). Climate is the major driver of both species and land-cover distributions (BARBET-MASSIN et al., 2012; ThuiLler et al., 2004). Climate and habitats can simultaneously lead to shifts in species distribution (Velásquez-Tibatá et al., 2013). The determinants of bird species distributions are hierarchically structured. A series of partial canonical ordinations were used to decompose species-environment relationships across hierarchical levels of organization to test different hypotheses about the importance of environmental control over community structure (CUSHMAN and MCGARIgAL, 2004). Climate variables are the determinants of the ecological niche on a large scale. Land cover becomes important at more granular spatial resolution (VIRKKALA, 2016). The integration of climate and land cover information can increase the predictive capabilities of biogeographic process models under conditions of global climate change (Luoтo et al., 2007). Climatic changes affect species range limits through processes that occur on a very local scale, including local adaptation, competitive exclusion, gradual dispersion and changes in biotic interactions (SEXTON et al., 2009). Species are often absent in a suitable habitat and are present in an unsuitable habitat as predicted by the theory of the ecological niche (Pulliam, 2000). Implemented climate niches of species depend to varying degrees on ecological characteristics of their habitats, as the integration of climate variables and information on preferred habitats in species distribution models has a controversial impact on their predictive efficiency (JETZ et al., 2007; LuOTO et al., 2007; THUILLER et al., 2004).

The selection of appropriate environmental predictors of the niche is the key condition for the reliability of statistical models (AUSTIN and VAN Niel, 2011). The proximal gradient is the causal variable determining the species response. The proximal variables determine the quality of the models as they are directly related to the regulation of physiological processes in individuals of the studied species (AUSTIN, 2002). Indirect gradients have no physiological effect on growth, development or competition (Piedallu et al., 2016). The variables that characterize indirect gradients are used in modeling species' responses to environmental factors and such variables are distal (Austin, 1980). Models of species distribution will have only a local value either for prediction or for explanation when distal variables are used (BRADIE and LeUnG, 2017; GARDNER et al., 2019; Merow et al., 2014). Direct gradients have a direct effect on species' physiology, while resource gradients create species' living conditions. Models based on proximal resource and direct gradients will be the most reliable and widely applicable (Austin, 2002; Elith et al., 2011). The species distribution models often use predictors that do not reflect the most important physiological features of species response to environmental factors. These are usually variables that reflect either seasonal or annual precipitation as simple surrogates of available plant moisture and neglect more direct measures such as soil water content. Predictors are usually results of seasonal or annual averaging and do not take into account the importance of climatic events during the critical period of a species' phenology (GARDNER et al., 2019).

Thus, global climate change affects the living conditions of individual species and their communities. These changes may affect the landscape diversity. In turn, the different types of ecosystems and climatic conditions determine a spatial distribution of species in space and time. The reliability of models based on climate predictors depends on the extent to which a relationship exists between a variable and biological features of a species. The models which use variables that reflect the causal relationships between environmental factors and species response are robust.

The objectives of the study were: 1) to evaluate the rate of temperature and precipitation increase during the first half of the year as proximal predictors of the ecological niche of birds; 2) to reveal the features of the response of bird populations to temperature and humidity gradients depending on ecosystem types; 3 ) to assess the influence of climatic changes on the temporal dynamics of bird communities.

\section{Material and methods}

\section{Types of ecosystems investigated}

The study was conducted in the landscapes of south-eastern Ukraine during the nesting seasons 1988-2018. Within the 
landscape system associated with the Molochny Estuary, the ten most important ecosystem types were investigated, including the following: agricultural land, vegetated strips within or around fields, meadows, islands and spits, reedbeds, urban areas, salt marshes, steppe, cliffs, artificial forests. The Molochny Estuary is located within the northwestern coast of the Sea of Azov (46 $33^{\prime} \mathrm{N}, 35^{\circ} 24^{\prime} \mathrm{E}$ ). The average depth of the estuary is $1.5-2.0$ meters. The maximum length of the estuary is $36 \mathrm{~km}$, the greatest width $-9 \mathrm{~km}$ in the southern part and the smallest $-4 \mathrm{~km}$ in the middle part of the water area. The total area of the estuary with the maximum water level is 21,945 thousand hectares. In the northern part, the Molochnaya River flows into the estuary, forming a delta with several branches. The southern part of the estuary is separated from the Sea of Azov by the whole body of the spit Peresyp, formed by sand and shell sediments (VOROVKA and DEMCHENKo, 2019). The Molochny Estuary is periodically connected to the Sea of Azov by an artificially created channel. Water salinity depends on season, precipitation and the degree of isolation of the estuary from the sea. In the years of strong desalination salinity decreased to $4-7 \mathrm{~g} \mathrm{l}^{-1}$, and in low water periods the salinity of the water of the Molochny Estuary sharply increases.

\section{Field data collection}

Bird surveys were conducted using the transect method (BiBby et al., 2000; Blinkova et al., 2020; Novikov, 1953). The width of the survey corridor with good visibility was $7-8 \mathrm{~km}$, during rain $-2-4 \mathrm{~km}$, in fog - up to $500 \mathrm{~m}$ (in the specified boundaries it was maximum for larger species, and minimal - for small birds and individuals which were in closed habitats with limited visibility). Point surveys were held during stops during the scanning of uniform open areas. In all cases, the territory was examined using $12-\mathrm{X}$ binoculars and $60-\mathrm{X}$ telescopes. Depending on the duration of the day and the quality of the light, the counts were carried out throughout the daylight hours from 7:00 $7: 30$ to $15: 30-16: 00$. The counts were recorded on special cards, applied to the scale of 1:200,000 maps, and then transferred to the geographic information database created in the software ArcMap 10.0.

\section{Meteorological data}

The information on the temperature and precipitation during 1988-2018 at the Henichesk weather station was obtained from the National Climatic Data Center (https:// www.ncdc.noaa.gov) with the help of the rnoaa package (Chamberlain, 2020) for a language and environment $R$ for statistical computing (R CORE TEAM, 2020).

\section{Multivariate ordination techniques}

The multivariate ordination techniques were applied to analyze the spatiotemporal variation in the bird species composition. Prior to analyses, species data were Hellingertransformed (Pierre Legendre and GallaGHer, 2001). We subjected the Hellinger-transformed abundance matrix of species to constrained correspondence analysis (CCA) to extract the major patterns of variation (LEGENDRE and Birks, 2012; Ter BraAK and Šmilauer, 2015). The constrained ordination approaches allowed assessment of the effects of the temperature, precipitation and year as an explanatory variable on the bird community.

\section{Statistical techniques}

Huisman, Olff and Fresco hierarchical models (HOF) and Jansen-Oksanen models were used for explanation of the bird species response to the temperature or precipitation effects (Huisman et al., 1993; JANSEN and OKSANEN, 2013). Huisman, Olff and Fresco (HuISMAN et al., 1993) hierarchical models (HOF) along with a symmetric response also include a skewed response. Apart from the five HOF-models, two bimodal (skewed and symmetric) response shapes were included to cope with species that are restricted to gradient extremes due to competition (JANSEN and OKSANEN, 2013; Michaelis and Diekmann, 2017). The Huisman-Olff-Fresco models expanded by Jansen-Oksanen (HOFJO) are ranked according to the increasing complexity of biological information contained (Huisman et al., 1993; JANSEN and OKSANEN, 2013). Model I: no significant trend in space or time. Model II: an increasing or decreasing trend where the maximum is equal to the upper bound M. Model III: an increasing or decreasing trend where the maximum is below the upper bound M. Model IV: increase and decrease by the same rate - symmetrical response curve. Model V: increase and decrease by different rates - skewed response curve. Model VI: bimodal symmetric responses. Model VII: bimodal skewed responses. Huisman-Olff-Fresco models were fitted in the $\mathrm{R}$ statistical program (v. 3.3.1) (R Developmental Core Team, 2019) using the package "eHOF" (JANSEN, 2013). To improve modeling results even for small data sets, the stability of model choice was double-checked by bootstrapping (100 samplings, default package setting) to ensure model robustness. The Akaike information criterion corrected for small data sets (AICc) was used (BURNHAM and ANDERSON, 2002). In cases when the two procedures differed in their choice for the best model type, the bootstrapping model was preferred (Michaelis and Diekmann, 2017).

The dynamics of bird communities was assessed using the Community Trajectory Analysis (CTA) in the CCAaxis space. The calculations were performed using the package vegclust (DE CÁCERES et al., 2010, 2019). The types of trajectories of temporary changes in communities are given in accordance with an article by Matthews et al. (Matthews et al., 2013). For the statistical analyses we used the appropriate procedures of Statistica (Version 5.5, StatSoft Inc., http://www.statsoft.com) or R (R CORE TEAM, 2020).

\section{Results}

The average daily temperatures during the first half of the year were found to be linearly dependent on the ordinal number of the day (Fig. 1A). The slope of the straight line 
indicates the warming rate in a given year. This statistic was used to characterize the temperature regime of each of the years within the time range of the research. The warming rate and the average annual temperature were not statistically significantly correlated $(r=0.10, p=0.59)$. The average annual temperature during the period of the investigations showed a tendency to increase, which was confirmed by a positive correlation with the ordinal value of the year $(r=0.59, p<0.001)$ (Fig. 1). At the same time, the warming rate in the first half of the year was stationary during the period of studies (the correlation with the ordinal value of the year was $r=0.29, p<0.11$ ).

A)

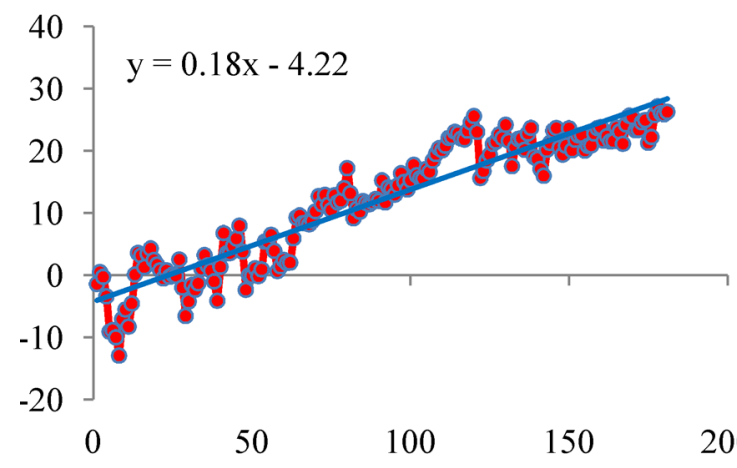

B)

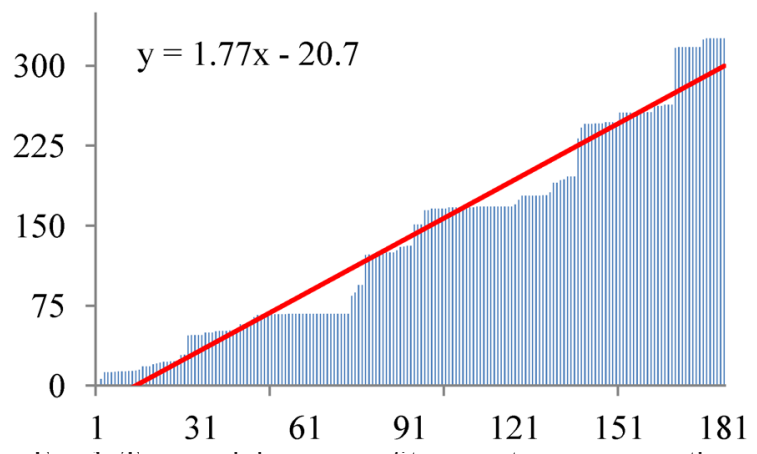

Hig. 1. Iemporal dynamics of temperature course in the first half of 2005 (A) and cumulative precipitation (B). The abscissa axis is the order of days, starting from January 1; the ordinate axis is the temperature, ${ }^{\circ} \mathrm{C}(\mathrm{A})$; cumulative precipitation is the sum of precipitation with cumulative total for the previous days before this, $\mathrm{mm}(\mathrm{B})$.

The cumulative precipitation formed a trend, which can be described by a linear dependence (Fig. 1B). The slope of the straight line indicates the precipitation intensity in a given year and can also be used to characterize the precipitation regime. For the period of studies there was observed a trend of annual precipitation increase (correlation with the order of years was $r=0.36, p=0.04$ ) (Fig. 2). The annual precipitation and rate of precipitation in the first half of the year were strongly correlated ( $r=$ $0.62, p<0.001)$. This explains the fact that the rate of precipitation in the first half of the year was also subject to an increasing trend over time $(r=0.57, p<0.001)$ (Fig. 3).

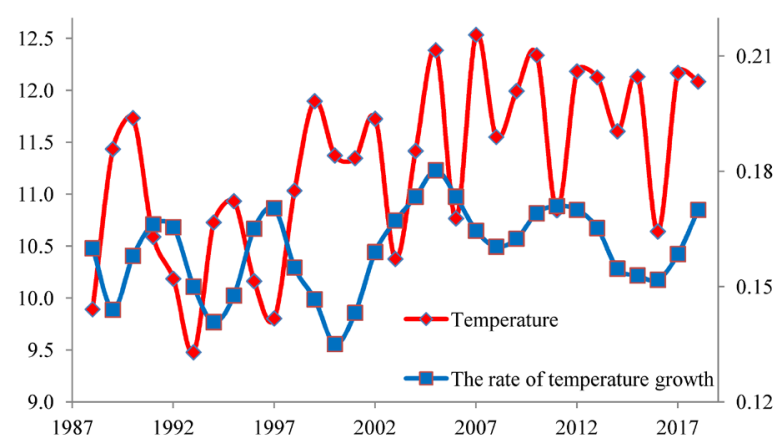

Fig. 2. Temporal dynamics of average annual temperature (red line) and temperature growth rate in the first half of the year (blue line). The abscissa axis is the order of years 1998, ..., 2018; the ordinate axis is the average annual temperature (on the left, ${ }^{\circ} \mathrm{C}$ ); on the right is the average rate of temperature growth in the first half of the year (right, ${ }^{\circ} \mathrm{C} /$ day).

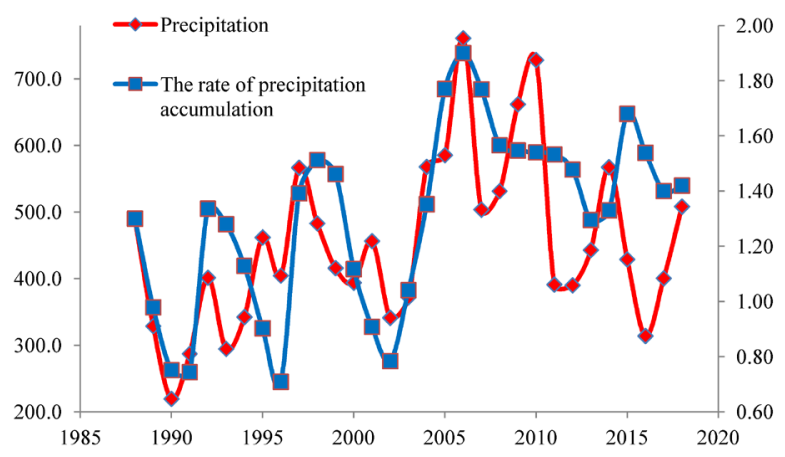

Fig. 3. Temporal dynamics of annual precipitation (red line) and precipitation accumulation rate in the first half of the year (blue line). The abscissa axis is the order of years 1998, ..., 2018; the ordinate axis is the annual precipitation (on the left, $\mathrm{mm}$ ); on the right is the average rate of precipitation accumulation in the first half of the year (right, $\mathrm{mm} /$ day).

Bird species responded to temperature and precipitation gradients. The patterns of responses were presented using seven models (Fig. 4). Species that were found in more than one ecosystem type could show different patterns of response to similar environmental gradients (Table 1). It should be noted that in $38.24 \%$ of cases, the response of species to temperature was explained by the model I, which indicated the lack of a clear response to temperature variation (Fig. 5). In $34.5 \%$ of cases the response to precipitation gradient was also explained by the model I. The monotonic patterns of response (models II and III) were found to be suitable only in $11.8 \%$ of cases of response to temperature influence and in $20.6 \%$ of cases of response to precipitation gradient. The non-monotonic response patterns (unimodal - IV and V, as well as bimodal - VI and VII) were most typical for explaining the response of bird species to environmental gradients. To explain the response to temperature gradient, the nonmonotonic models were the most preferable in $50.0 \%$ of cases, and to model the response to precipitation gradient were the most preferable in $44.9 \%$ of cases. 

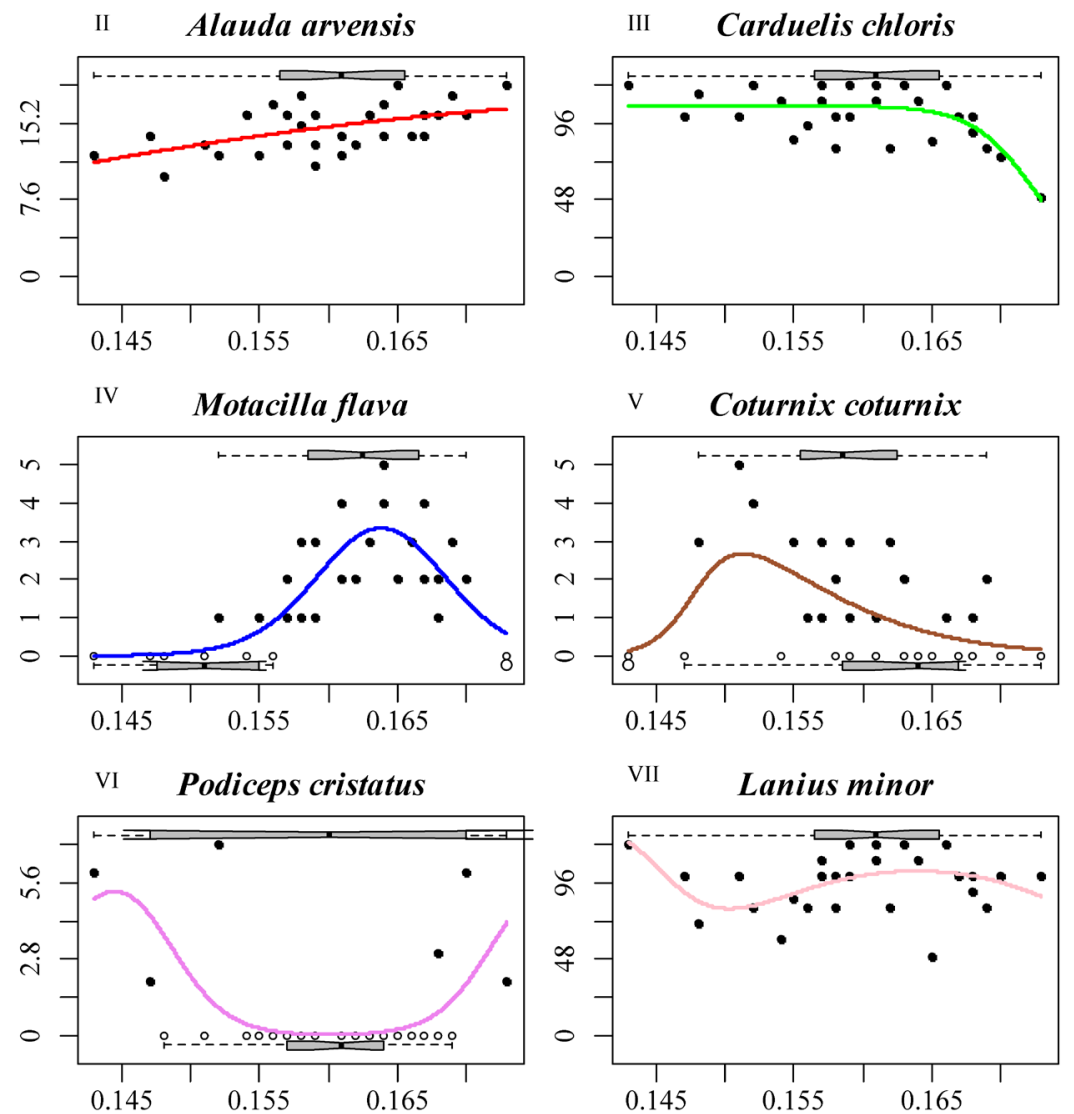

Fig. 4. HOFJO-models of species response to environment gradient. X-axis is the temperature growth rate in the first half of the year; Y-axis - the number of individuals. HOFJO-models: II - an increasing or decreasing trend where the maximum is equal to the upper bound; III - an increasing or decreasing trend where the maximum is below the upper; IV - increase and decrease by the same rate - symmetrical response curve; $\mathrm{V}$ - increase and decrease by different rates - skewed response curve; VI - bimodal symmetric responses; VII - bimodal skewed responses.

A)

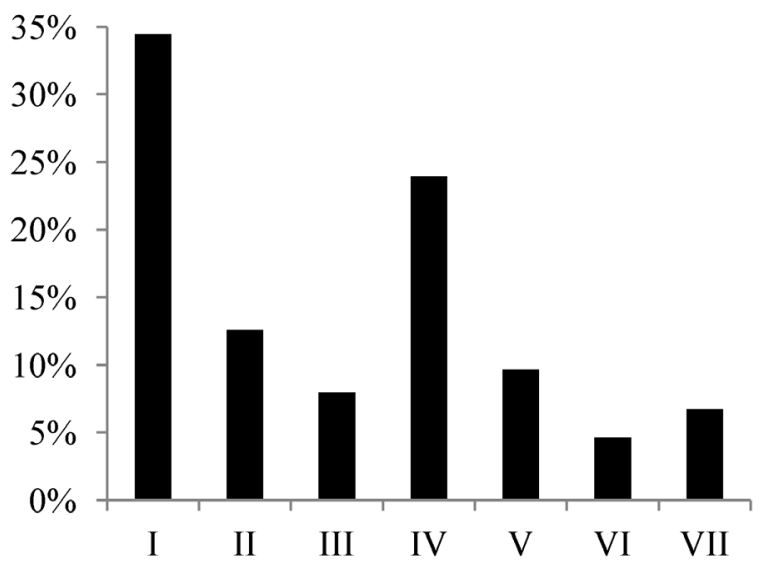

B)

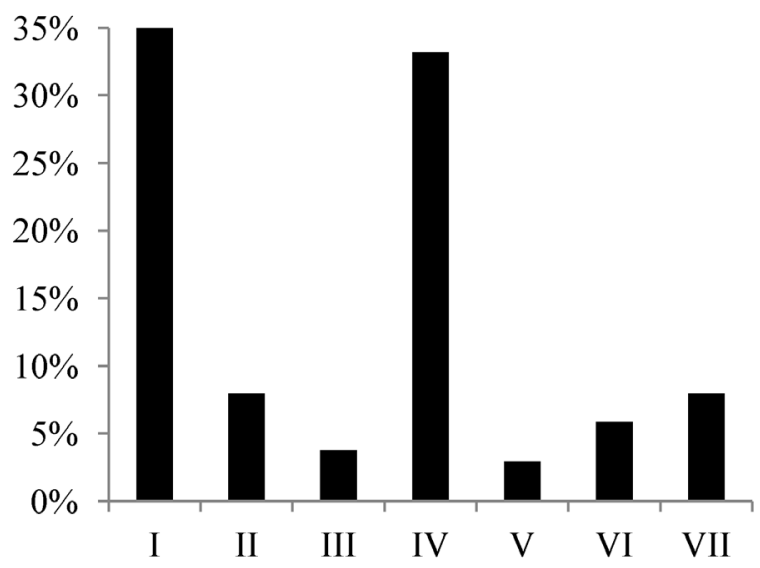

Fig. 5. The optimal models distribution of species response to the environment gradients. A - the temperature growth rate in the first half of the year; B - the precipitation accumulation rate in the first half of the year. X-axis - HOF and two additional models of the species responses to the soil moisture gradient, Y-axis - the \% of the total number

of species for which a model is the best according to AICc. HOFJO-models: I - no significant trend in space or time; II - an increasing or decreasing trend where the maximum is equal to the upper bound; III - an increasing or decreasing trend where the maximum is below the upper; IV - increase and decrease by the same rate - symmetrical response curve; $\mathrm{V}$ - increase and decrease by different rates - skewed response curve; VI - bimodal symmetric responses; VII - bimodal skewed responses. 


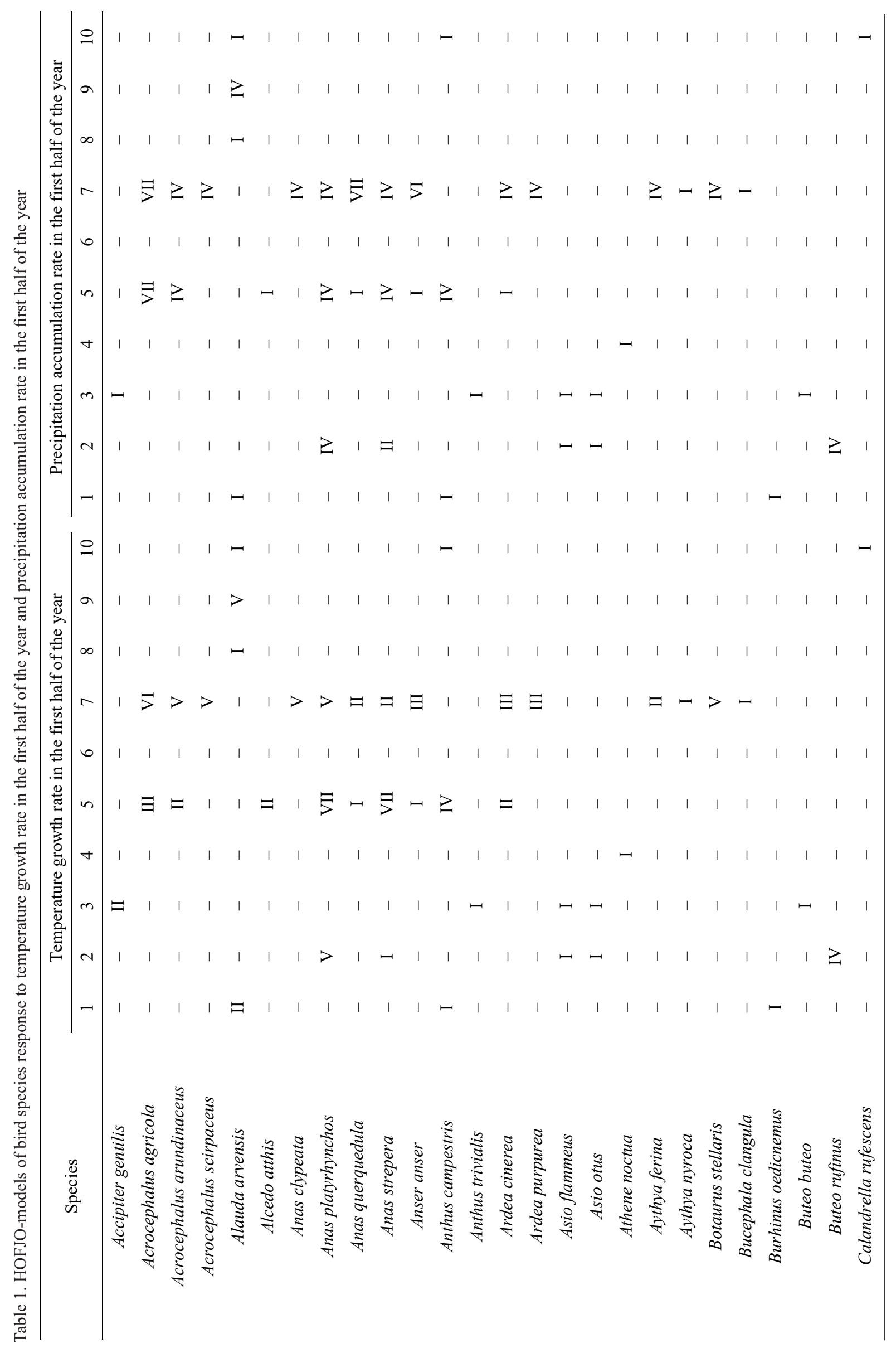




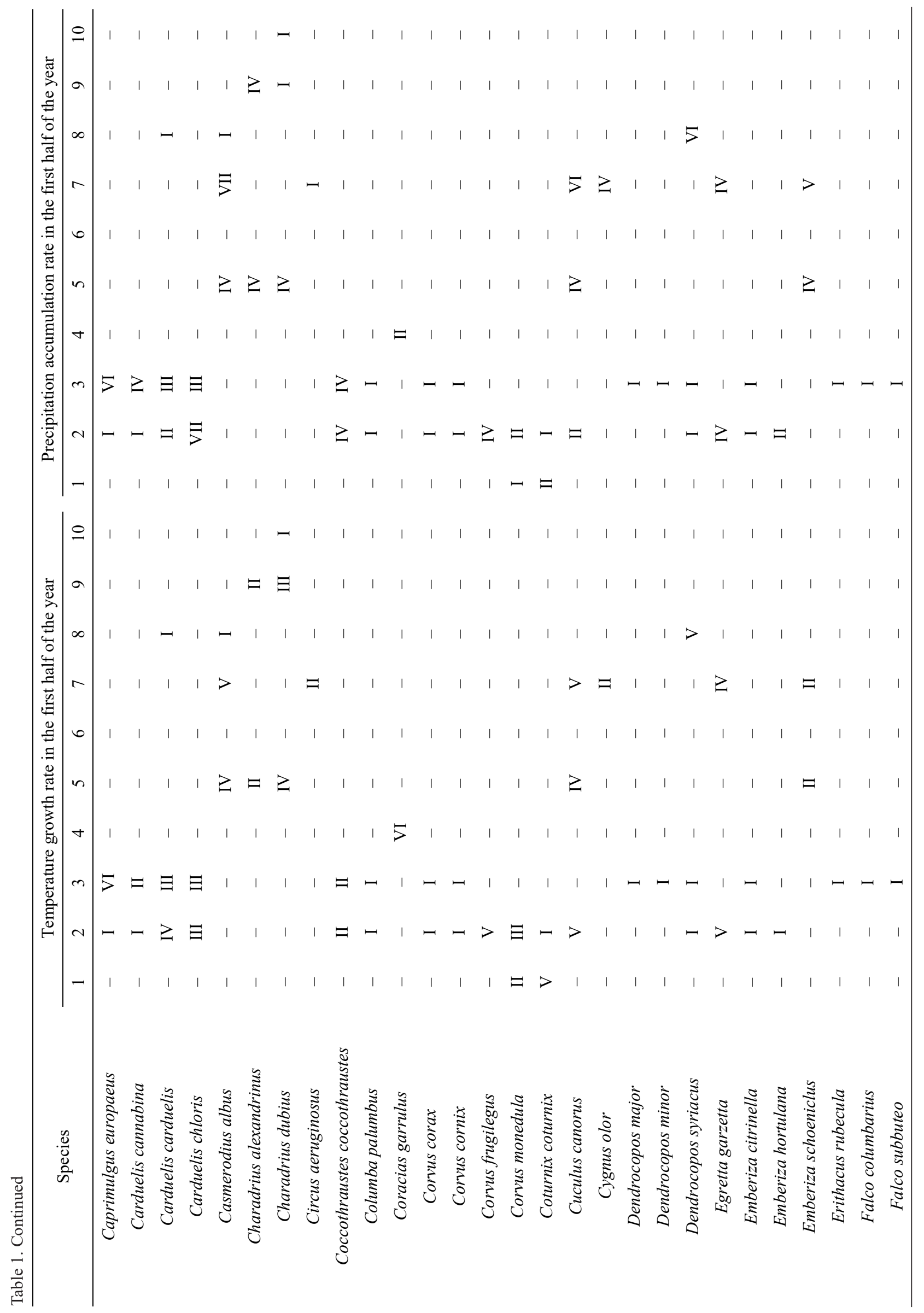




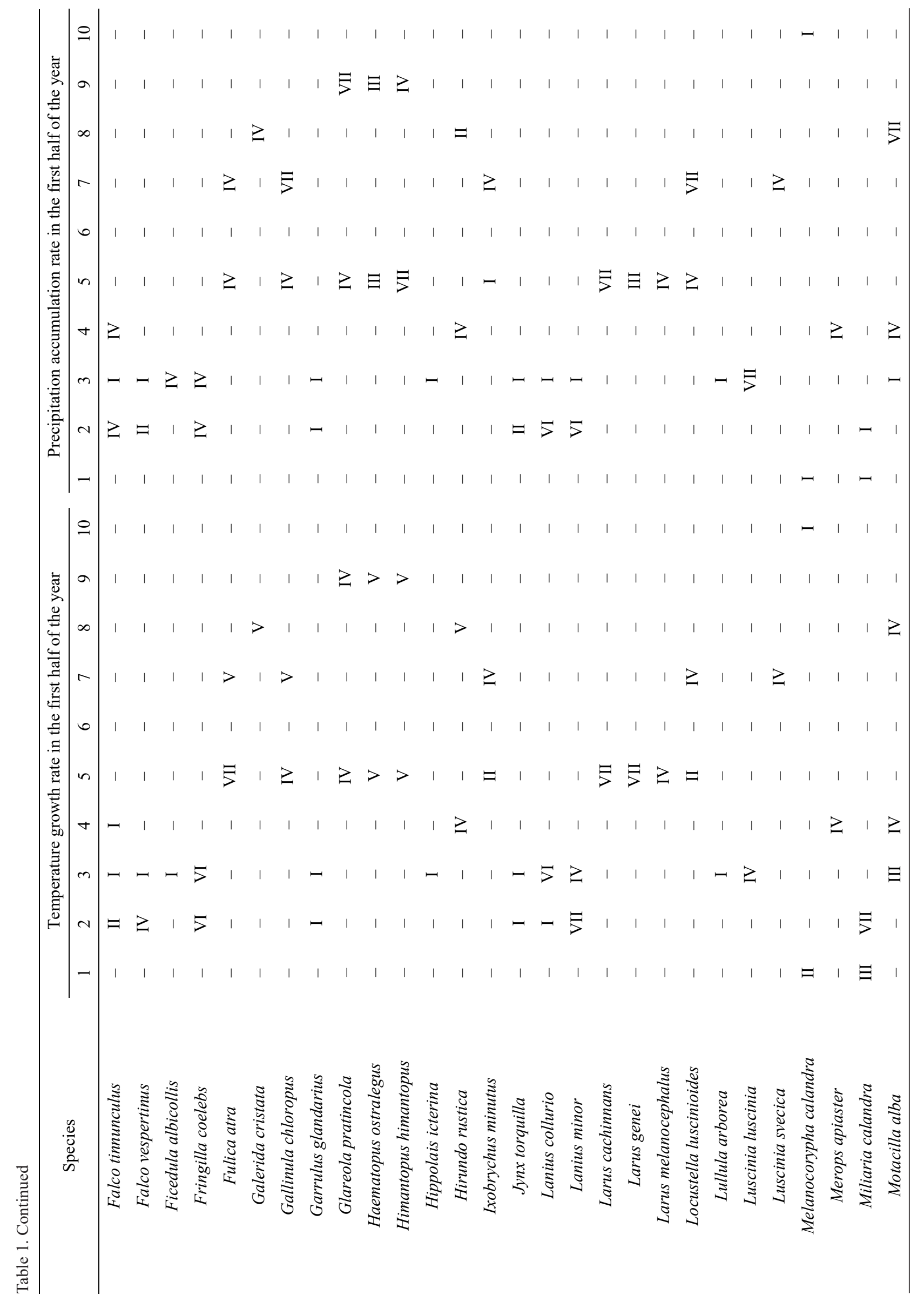




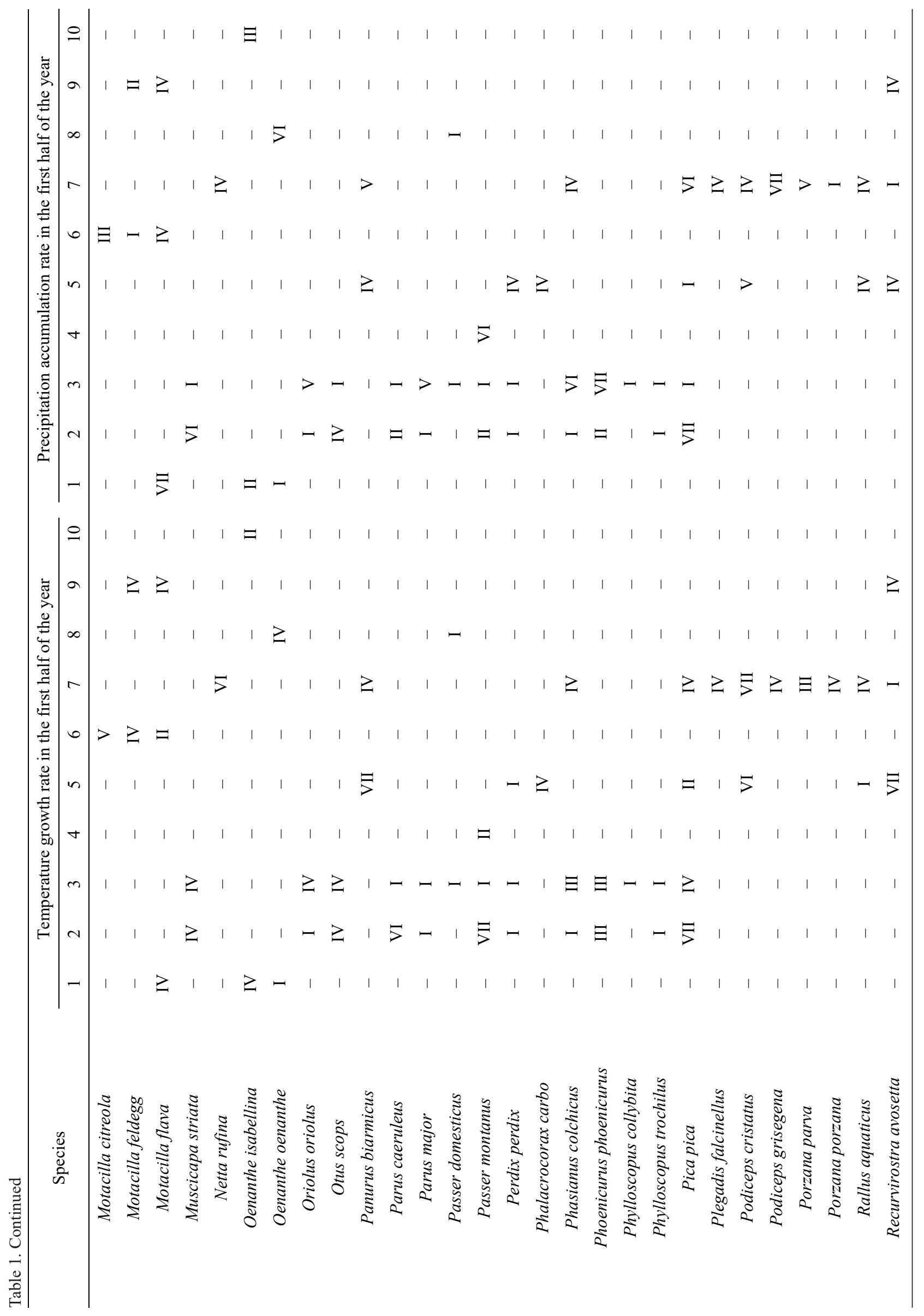




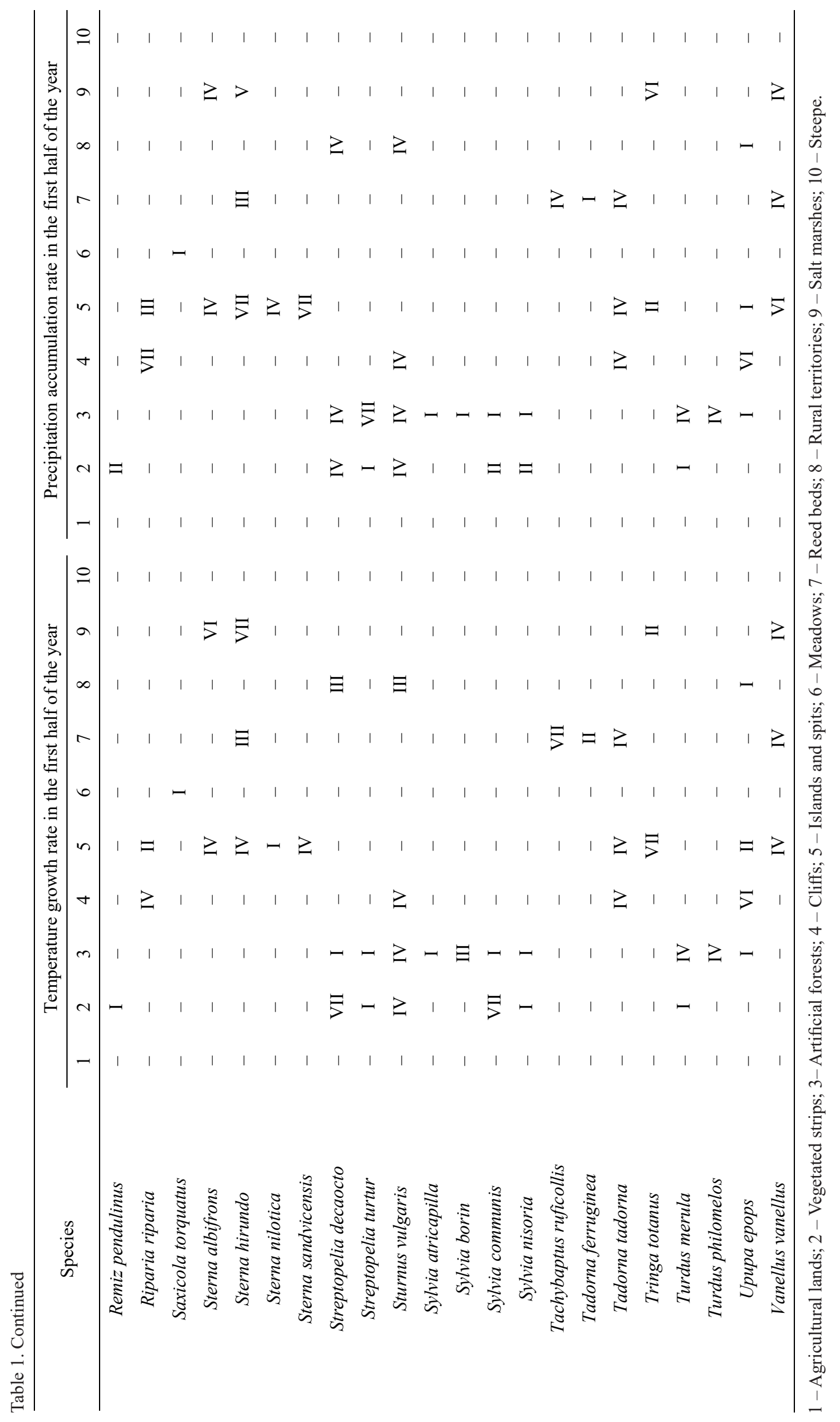


The rates of temperature and precipitation increase in the first half of the year and the year as predictors were able to explain 5-51\% variation of bird communities over time depending on the type of biotope (Table 2). These predictors were most important to explain the variation in bird community structure from Vegetated strips and Meadows. The bird communities from Cliffs and Islands and spits were the least sensitive to these predictors. Axis 1 , extracted as a result of the CCA procedure, tended to reflect the time trend of community variability, which was closely related to the increase in temperature and precipitation. Axis 2 was not associated with a linear time trend in half of the cases. For bird assemblages from Islands and spits, axis 2 indicated a variation in response to rainfall. For Steppe communities, this axis indicated the community's response to the temperature factor. For other communities, axis 2 indicated different combinations of temperature, precipitation and time effects on the variation of bird communities.

The trajectories of bird assemblages in the space of axes 1 and 2, which were extracted as a result of CCA procedure, indicated the presence of two or more quasicyclic states of the communities, the transition between which was almost saltatory (Fig. 6). The exception was the Steppe community, which exhibited a chaotic dynamic. The length of the trajectory was the longest for bird communities from Steppe and Meadows (Table 3). Obviously, the trajectory length indicated the degree of the community transformation over time. Bird communities from Salt marshes, Meadows, and Urban areas had the lowest mean

Table 2. Results of RDA ordination for bird communities from different biotopes with rates of temperature increase and precipitation in the first half of the year and year as predictors (only statistically significant correlation coefficients are shown)

\begin{tabular}{|c|c|c|c|c|c|c|c|}
\hline \multirow{2}{*}{ Biotope } & \multicolumn{3}{|c|}{ CCA1 } & \multicolumn{3}{|c|}{ CCA2 } & \multirow{2}{*}{$R_{a d}^{2}$} \\
\hline & Temp & Prec & Year & Temp & Prec & Year & \\
\hline Agricultural lands & 0.47 & 0.67 & 0.98 & -0.88 & - & 0.19 & 0.16 \\
\hline Vegetated strips & 0.65 & 0.53 & 0.91 & -0.76 & - & 0.40 & 0.47 \\
\hline Artificial forests & -0.44 & -0.94 & -0.81 & 0.20 & 0.31 & -0.59 & 0.12 \\
\hline Cliffs & - & 0.46 & 0.95 & 0.98 & 0.23 & 0.29 & 0.10 \\
\hline Islands and spits & - & 0.51 & 0.99 & - & 0.81 & - & 0.20 \\
\hline Meadows & 0.36 & 0.62 & 0.99 & -0.71 & -0.63 & - & 0.51 \\
\hline Reed beds & 0.37 & 0.43 & 0.99 & -0.36 & 0.70 & - & 0.10 \\
\hline Rural territories & - & 0.46 & 0.99 & -0.81 & -0.73 & - & 0.36 \\
\hline Salt marshes & - & 0.39 & 0.97 & -0.62 & -0.88 & -0.23 & 0.29 \\
\hline Steepe & 0.26 & 0.99 & 0.53 & -0.96 & - & - & 0.05 \\
\hline
\end{tabular}

Table 3. Trajectory lengths, angles, overall directionality of temporal change in communities

\begin{tabular}{cccccc}
\hline Biotope & Jump time & Lengths & $\begin{array}{c}\text { Angles* } \\
\text { (Mean } \pm \text { st. deviation) }\end{array}$ & Rho** & $\begin{array}{c}\text { Directiona- } \\
\text { lity*** }\end{array}$ \\
\hline Agricultural lands & 1993,2003 & 29.54 & $94.79 \pm 0.93$ & 0.65 & 0.43 \\
Vegetated strips & 2011 & 36.41 & $69.64 \pm 1.06$ & 0.57 & 0.40 \\
Artificial forests & 2005 & 32.95 & $82.57 \pm 1.01$ & 0.60 & 0.39 \\
Cliffs & 2015 & 46.49 & $93.66 \pm 1.03$ & 0.59 & 0.40 \\
Islands and spits & 2010 & 33.74 & $79.53 \pm 0.94$ & 0.64 & 0.39 \\
Meadows & 1998 & 56.49 & $107.93 \pm 1.28$ & 0.44 & 0.33 \\
Reed beds & 2009 & 45.70 & $99.25 \pm 1.00$ & 0.60 & 0.40 \\
Rural territories & 2012 & 39.31 & $95.41 \pm 1.14$ & 0.52 & 0.41 \\
Salt marshes & 2006 & 37.59 & $95.77 \pm 1.19$ & 0.49 & 0.42 \\
Steepe & - & 118.03 & $117.66 \pm 1.18$ & 0.50 & 0.27 \\
\hline
\end{tabular}

* - angles between consecutive segments in degrees; zero values point to segments that are along a straight line, and values equal to 180 degrees correspond to segments that are in opposite directions; ** - rho: mean resultant length of circular statistics which takes values between 0 and 1 , and used to assess the degree of homogeneity of angle values and it will take a value of 1 if all angles are the same; $* * *$ - the measure of a overall directionality of a community trajectory and vary from 0 to 1 (the value 1 corresponds to the situation when all segments are located along a straight line). 

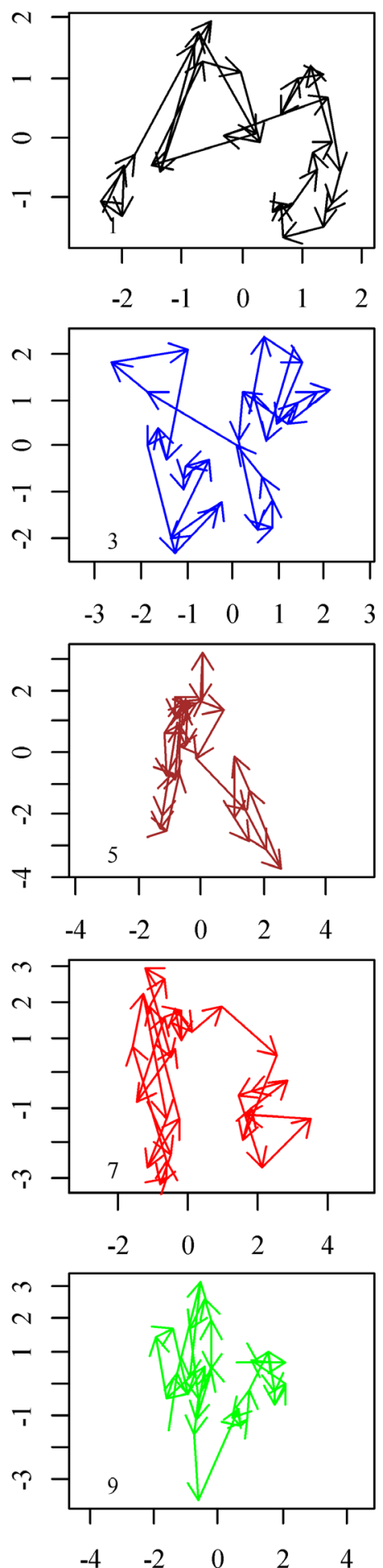
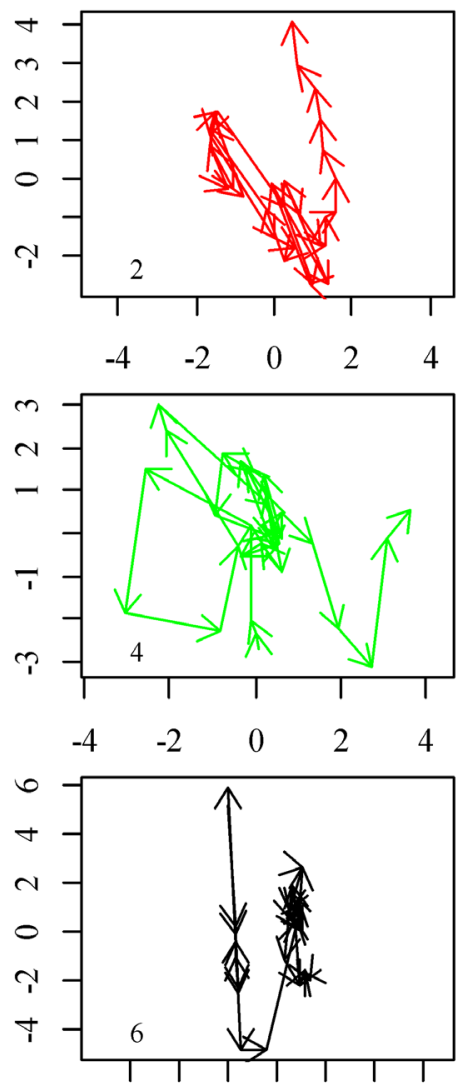

$\begin{array}{lllllll}-6 & -4 & -2 & 0 & 2 & 4 & 6\end{array}$
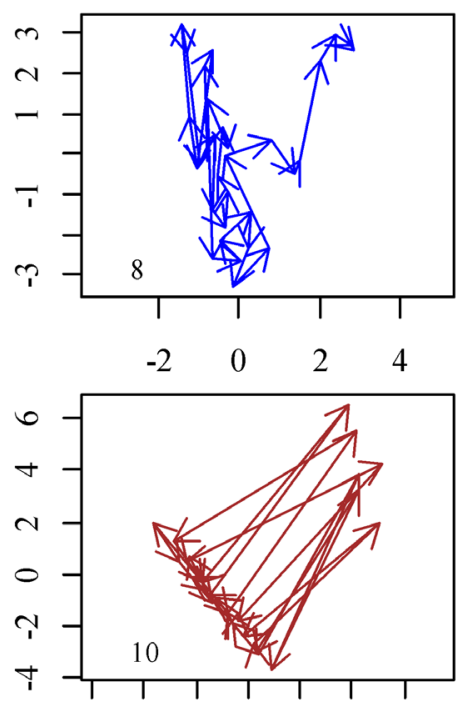

$\begin{array}{lllllll}-6 & -4 & -2 & 0 & 2 & 4 & 6\end{array}$

Fig. 6. Time trajectories of bird communities in the CCA axis space. The abscissa axis is CCA 1, the ordinate axis is CCA 2 , and segments are transitions of the community state in successive years: 1988-1989, 1989-1990, ..., 2017-2018. The arrows show the directions of transitions. 1 - Agricultural lands, 2 - Vegetated strips within or around fields, 3 - Cliffs, 4 - Islands and Spits, 5 - Meadows; 6 - Reedbeds, 7 - Urban territories, 8 - Salt marshes, 9 - Steppe, 10 - Artificial forests.

resultant length of the circular statistics (rho). Thus, for the specified habitats the degree of homogeneity of angle values was the lowest, which indicated greater chaotic dynamics. In turn, the highest degree of homogeneity of angle values was found for bird communities from the Steppe, Islands and spits, Agricultural lands.

\section{Discussion}

Global climate change affects the regimes of the most important meteorological variables, such as temperature and precipitation (KonAPALA et al., 2020). The temperature regimes influence various aspects of bird 
biology (MAYFIELD et al., 2012; ReIF et al., 2010; WATTS et al., 2018). The synchronization of the phenological stages of development of food objects with the breeding dynamics of birds is an important requirement for successful reproduction of birds (HALUPKA and HALUPKA, 2017; PAKhomov et al., 2019; Perrins, 2008). The beginning of the breeding time of birds and the time of peak appearance of the food objects progressed due to the warming of the climate and was well explained by spring temperatures (VATKA et al., 2011). The spring phenological events show an earlier trend in the response to increasing spring temperatures (CARROLL et al., 2009). The role of precipitation is also important as a factor regulating the rhythm of the vegetation cover and the phenology of possible food objects for birds of plant origin (ZHOU and JIA, 2016). The state of plants also affects the animals on which the birds in turn feed (MÄNTYLÄ et al., 2011; ZHANG et al., 2018).

The landscape system considered covers a range of biotopes from steppe to aquatic ecosystems, for which the role of precipitation is crucial. There is a lack of water in the steppe communities, so the role of this environmental factor is extremely important. In wetland ecosystems, the precipitation regime determines the ratio of land or water surface in the respective areas, which affects the extent of island spaces. The island character of many locations is very important as a factor in protecting birds from predators (Clode and Macdonald, 2002; Côté and Sutherland, 1997; SмIтH et al., 2010). The precipitation also affects the level of salinity of soil and water bodies, which also significantly affects the structure of the vegetation cover and trophic objects of birds (SHRIVASTAVA and KuMAR, 2015).

However, the evaluation of the role of temperature and precipitation in the ecosystem dynamics suggests that these phenomena should be represented as the quantitative variables that can be used to model their role in a description of the state of bird populations and communities. The complexity of the problem is that the phenology is significantly different for different bird species. The most sensitive stages of life cycle for different bird species occur in different periods of the year. Therefore, the general variables such as the average annual temperature or the amount of precipitation for a year or other artificially specified period have a distant relation to the dynamics of the bird life cycle. In ecology, agriculture, forestry and hydrology the effective sum of temperatures is widely used, which is the sum of positive differences between the average diurnal temperature and a commonlyused threshold of temperature $5^{\circ} \mathrm{C}$ (Heikinheimo and LAPPALAinen, 1997; Thum et al., 2009).

Under conditions of the linear temperature growth over time, which is observed in the first half of the year within the studied territory, the sum of effective temperatures will be proportional to the temperature increase rate. To study the coordinated changes in populations of different species in response to changes in the climatic conditions, the rate of temperature change eliminates the need to explicitly determine the sum of effective temperatures for the different species, which is practically very difficult to perform. In addition, the rate of temperature increase is actually an invariant value for the thermal regime of a given year. It should be noted that the rate of temperature increase during the first half of the year does not demonstrate a stable growth trend throughout the whole period of research in contrast to the average annual temperature. The trend of average temperature increase can be explained by a global warming. The obtained results indicate that within the studied area the warming is shifted mostly to the second half of the year, when the main events related to the breeding of birds have already been completed. This result largely explains the observation that climatic changes are less important than landscape features of an area in terms of the variation of bird community structure (BONTHOUX et al., 2013; Crick, 2004; Trautmann, 2018; Triviño et al., 2011).

The quantification of precipitation dynamics is also a challenging task. The precipitation in the steppe zone should be also noted to be extremely irregular (KUNAH et al., 2019; MARCuZZI, 1979). The soil water balance depends on the daily precipitation and the actual evapotranspiration (TeixeIra and Pereira, 1992). Therefore, the cumulative sum of precipitation can be considered as a fairly good approximation that characterizes the water balance. The cumulative precipitation indicator gives a smoothed representation of the moisture dynamics (BONDAREV et al., 2019; Bondarev and ZhuKov, 2017). This indicator also reflects the presence of phenomena of moisture accumulation in the soil and water bodies, which provides a basis for the summation of the precipitation over a period.

The results obtained indicate that the birds did not show a significant pattern of response to the changes in temperature and precipitation in at least one third of the cases. According to 'Shelford's law of tolerance', all populations staying in the optimal condition do not demonstrate an unambiguous response to the ecological factors (SHELFORD, 1931). In contrast, switching the ecological factor from the pessimum to the optimum is commonly accompanied by the sensitive reaction of populations (AlaSMARY et al., 2020; KUNAH et al., 2018). It is possible to assume that the species which are in an optimum zone do not appear insensitive to the variability of environmental factors. Thus, the observed climate changes for a considerable proportion of bird species do not exceed the limits of the optimum. Nevertheless, for $2 / 3$ of the bird species, changes in the climatic conditions which are reflected in the variability of temperature and precipitation, affect their abundance. It is important to note that the nature of species response in the gradient of temperature or precipitation conditions depends on the type of particular ecosystem and is not uniform for all populations inhabiting the different landscape conditions. The results obtained are in accordance with the assumption that the responses to climatic warming are population, species and habitat specific (VATKA et al., 2011). The bimodal response types are associated with the role of biotic interactions such as the interspecific competition (AUSTIN, 1976; BATEMAN et al., 2012; JANSEN and OKSANEN, 2013). The bimodality is also the basis for the significant community rearrangements, which manifest 
themselves as the discontinuous transitions of trajectories. Abrupt dynamics over time were observed for the bird communities of most of the ecosystem types studied. No drastic changes in the climatic conditions during the study period were detected. Therefore, we can conclude that the continuous changes in a community's structure initiated by the external environmental factors combined with changes in the internal biotic interactions, which is exactly what can lead to a drastic reorganization of the community. The climate changes have different effects on the distribution of resources in the various areas, creating a mismatch in resource use and availability between species (PIMm, 2009). This mismatch will eventually lead to cascading effects and asynchrony between reactions of different trophic groups, increasing negative and positive cumulative impacts of climate change on ecological communities (BELlard et al., 2012; Brown et al., 1997; Martin and Maron, 2012; MurPhy et al., 2020).

The variables considered, which describe temperature and precipitation conditions, can also explain the dynamics of bird communities. For community ordination, Redundancy Analysis or Correspondence Analysis may be considered as alternatives (VAN DEN WOLLENBERG, 1977). In comparison with other ordination techniques, these approaches have a constrained version (O'CONNOR, 1988; OKSANEN, 2012). The choice between these two techniques depends on the preferred type of species response to the effects of environmental gradients (TER BRAAK and Prentice, 1988). In case of monotonic responses, Redundancy Analysis has an advantage, while in case of bell-shaped responses, Correspondence Analysis has an advantage. The response of bird species to temperature and precipitation gradients most often has a symmetrical or asymmetrical bell-shaped type of response. It should be noted that the biomodal response type can be considered as a result of the strong competitive relationships of species in the optimum zone. Thus, Constrained (or Canonical) Correspondence Analysis (CCA) proved to be the most appropriate procedure for the ordination of bird communities.

For all communities, there was a trend of directed changes that is marked by a time variable. The increases in temperature and precipitation are associated with this trend. However, the correlation of these factors is specific to the different types of ecosystems. It should be noted that the importance of temperature may be lower than the role of precipitation or neutral trends for some ecosystems. Also, the community may not show a stable response to temperature changes. For example, no significant role of temperature was found for the bird communities of islands and spits. With global warming, the role of change in the rhythm of precipitation in the steppe zone is more important than temperature dynamics. These conclusions are in line with findings that the arid steppes with low vegetation productivity can respond strongly to the changing precipitation patterns, especially when warming occurs, highlighting the positive effects of increased precipitation on warming (XU et al., 2016). Obviously, the specificity of the impact of precipitation on vegetation cover and living birds has a clearly defined landscape context. The degree of sensitivity to precipitation may vary significantly in different types of ecosystems. In addition, the mechanism of such influence will be different. In steppe ecosystems, the additional amount of water may stimulate plant growth and expand the trophic base for birds. In wetland ecosystems, the precipitation has a significant impact on the water levels in water bodies, which determines the areas suitable for nesting and the degree of protection of sites from the predators. In brackish estuaries, the precipitation affects the degree of salinity in water bodies and their level of food resources, which also determines the trophic base of the shorebird species.

\section{Conclusion}

The regime of temperature and precipitation has a significant impact on the temporal dynamics of both the studied bird populations and their communities. The warming and precipitation rates in the first half of the year may be considered as the proximal predictors both on species and community level. The type of response of bird populations to temperature or precipitation gradients varies depending on the ecosystem type. In the context of global warming, the role of changes in precipitation patterns is more important than changes in the temperature in transforming bird communities. The dynamics of bird communities under the influence of climatic factors are undergoing abrupt transitions, which are most likely due to the restructuring of biotic interactions within the communities.

\section{Acknowledgements}

The authors thank Paul Bradbeer (Alfred Nobel University, Dnipro, Ukraine) for checking the English text and the two anonymous reviewers for helping us to improve earlier versions of this paper.

\section{References}

Alasmary, Z., Todd, T., Hettiarachchi, G.M., Stefanovska, T., Pidlisnyuk, V., Roozeboom, K., Zhukov, O., 2020. Effect of soil treatments and amendments on the nematode community under Miscanthus growing in a lead contaminated military site. Agronomy, 10 (11): 1727. https://doi.org/10.3390/agronomy10111727

Austin, M.P., 1976. On non-linear species response models in ordination. Vegetatio, 33 (1): 33-41. https://doi. org/10.1007/BF00055297

Austin, M.P., 1980. Searching for a model for use in vegetation analysis. Vegetatio, 42 (1-3): 11-21. https:// doi.org/10.1007/BF00048865

Austin, M.P, 2002. Spatial prediction of species distribution: an interface between ecological theory and statistical modelling. Ecological Modelling, 157 (2-3): 101-118. https://doi.org/10.1016/S0304-3800(02)00205-3

Austin, M.P., VAN NieL, K.P., 2011. Improving species distribution models for climate change studies: variable 
selection and scale. Journal of Biogeography, 38 (1): 1-8. https://doi.org/10.1111/j.1365-2699.2010.02416.x

Barbet-Massin, M., Thuiller, W., Jiguet, F., 2012. The fate of European breeding birds under climate, land-use and dispersal scenarios. Global Change Biology, 18 (3): 881890. https://doi.org/10.1111/j.1365-2486.2011.02552.x

Barnagaud, J.-Y., Devictor, V., Jiguet, F., Barbet-Massin, M., Le Viol, I., Archaux, F., 2012. Relating habitat and climatic niches in birds. PLoS ONE, 7 (3): e32819. https://doi.org/10.1371/journal.pone.0032819

Bateman, B.L., VanDerWal, J., Williams, S.E., Johnson, C.N., 2012. Biotic interactions influence the projected distribution of a specialist mammal under climate change. Diversity and Distributions, 18 (9): 861-872. https://doi. org/10.1111/j.1472-4642.2012.00922.x

Bellard, C., Bertelsmeier, C., Leadley, P., Thuiller, W., Courchamp, F., 2012. Impacts of climate change on the future of biodiversity. Ecology Letters, 15 (4): 365-377. https://doi.org/10.1111/j.1461-0248.2011.01736.x

Bibby, C., Burgess, N., Hill, D., Mustoe, S., 2000. Bird census techniques. 2nd ed. London: Academic Press. 302 p.

Blinkova, O., Shupova, T., 2018. Bird communities and vegetation composition in natural and semi-natural forests of megalopolis: correlations and comparisons of diversity indices (Kyiv city, Ukraine). Ekológia (Bratislava), 37 (3): 259-288. https://doi.org/10.2478/eko-2018-0021

Blinkova, O.I., Shupova, T.V., Raichuk, L.A., 2020. Synecological connections and comparison of $\alpha$-diversity indices of plant and bird communities on cultivated coenosises. Journal of Landscape Ecology, 13 (2): 62-78. https://doi.org/10.2478/jlecol-2020-0010

Bondarev, D.L., Kunah, O.M., FedushKo, M.P., Gubanova, N.L., 2019. The impact of temporal patterns of temperature and precipitation on silver Prussian carp (Carassius gibelio) spawning events. Biosystems Diversity, 27 (2): 106-117. https://doi.org/10.15421/011915

Bondarev, D.L., Zhukov, O.V., 2017. Spawning phenology of the white bream (Blicca bjoerkna) in the "DnieperOrylskiy" Nature Reserve in relation to seasonal temperature dynamic. Biosystems Diversity, 25 (2): 67 73. https://doi.org/10.15421/011710

Bonthoux, S., Barnagaud, J.-Y., Goulard, M., Balent, G., 2013. Contrasting spatial and temporal responses of bird communities to landscape changes. Oecologia, 172 (2): 563-574. https://doi.org/10.1007/s00442-012-2498-2

Bowler, D., BöHning-Gaese, K., 2017. Improving the community-temperature index as a climate change indicator. PLoS ONE, 12 (9): e0184275. https://doi. org/10.1371/journal.pone.0184275

Bradie, J., Leung, B., 2017. A quantitative synthesis of the importance of variables used in MaxEnt species distribution models. Journal of Biogeography, 44 (6): 1344-1361. https://doi.org/10.1111/jbi.12894

Brown, J.H., VAlone, T.J., CURTIN, C.G., 1997. Reorganization of an arid ecosystem in response to recent climate change. Proceedings of the National Academy of Sciences, 94 (18): 9729-9733. https://doi.org/10.1073/ pnas.94.18.9729

Burnham, K.P., ANDERSON, D.R., 2002. Model selection and multimodel inference: a practical information-theoretic approach. Berlin: Springer. 488 p.
Carroll, E., Sparks, T., Donnelly, A., Cooney, T., 2009. Irish phenological observations from the early 20th century reveal a strong response to temperature. Biology \& Environment: Proceedings of the Royal Irish Academy, 109 (2): 115-122. https://doi.org/10.3318/ BIOE.2009.109.2.115

Chamberlain, S., 2020. rnoaa: "NOAA" Weather data from $R$. $R$ package version 1.2.0. [cit.2021-10-31]. https:// cran.r-project.org/package $=$ rnoaa

Clode, D., Macdonald, D.W., 2002. Invasive predators and the conservation of island birds: the case of American Mink Mustela vison and terns Sterna spp. in the Western Isles, Scotland. Bird Study, 49 (2): 118-123. https://doi. org/10.1080/00063650209461255

Côté, I.M., Sutherland, W.J., 1997. The effectiveness of removing predators to protect bird populations. Conservation Biology, 11 (2): 395-405. https://doi. org/10.1046/j.1523-1739.1997.95410.x

CRICK, H.Q.P., 2004. The impact of climate change on birds. Ibis, 146: 48-56. https://doi.org/10.1111/j.1474919X.2004.00327.x

Cushman, S.A., McGarigal, K., 2004. Hierarchical analysis of forest bird species-environment relationships in the Oregon coast range. Ecological Applications, 14 (4): 1090-1105. https://doi.org/10.1890/03-5131

De Cáceres, M., Coll, L., Legendre, P., Allen, R.B., Wiser, S.K., Fortin, M., Condit, R., Hubbell, S., 2019. Trajectory analysis in community ecology. Ecological Monographs, 89 (2): e01350. https://doi.org/10.1002/ ecm. 1350

De CÁceres, M., Font, X., Oliva, F., 2010. The management of vegetation classifications with fuzzy clustering. Journal of Vegetation Science, 21 (6): 1138-1151. https:// doi.org/10.1111/j.1654-1103.2010.01211.x

De Frenne, P., Rodriguez-Sanchez, F., Coomes, D.A., Baeten, L., Verstraeten, G., Vellend, M., Bernhardt-Roemermann, M., Brown, C.D., Brunet, J., Cornelis, J., DecocQ, G.M., Dierschke, H., Eriksson, O., Gilliam, F.S., Hedl, R., Heinken, T., Hermy, M., Hommel, P., Jenkins, M.A., Kelly, D. L., Kirby, K.J., Mitchell, F.J.G., NaAf, T., Newman, M., Peterken, G., Petrik, P., Schultz, J., Sonnier, G., Van Calster, H., Waller, D.M., Walther, G.-R., White, P.S., Woods, K.D., Wulf, M., Graae, B.J., Verheyen, K., 2013. Microclimate moderates plant responses to macroclimate warming. Proceedings of the National Academy of Sciences, 110 (46): 18561-18565. https://doi. org/10.1073/pnas.1311190110

Devictor, V., Clavel, J., Julliard, R., Lavergne, S., Mouillot, D., Thuiller, W., Venail, P., Villéger, S., Mouquet, N., 2010. Defining and measuring ecological specialization. Journal of Applied Ecology, 47 (1): 15-25. https://doi.org/10.1111/j.1365-2664.2009.01744.x

Devictor, V., Julliard, R., Couvet, D., Jiguet, F., 2008. Birds are tracking climate warming, but not fast enough. Proceedings of the Royal Society B: Biological Sciences, 275 (1652): 2743-2748. https://doi.org/10.1098/ rspb.2008.0878

Devictor, V., van Swayy, C., Brereton, T., Brotons, L., Chamberlain, D., Heliölä, J., Herrando, S., Julliard, R., Kuussaari, M., Lindström, Å., Reif, J., Roy, D.B., 
Schweiger, O., Settele, J., Stefanescu, C., Van Serien, A., Van Turnhout, C., Vermouzek, Z., DeVries, M.W., Wynhoff, I., Jiguet, F., 2012. Differences in the climatic debts of birds and butterflies at a continental scale. Nature Climate Change, 2 (2): 121-124. https://doi.org/10.1038/ nclimate 1347

Dreslerová, J., 2017. Memorial trees in the Czech landscape. Journal of Landscape Ecology, 10 (2): 79-108. https:// doi.org/10.1515/jlecol-2017-0019

Elith, J., Phillips, S.J., Hastie, T., Dudík, M., Chee, Y.E., YATES, C.J., 2011. A statistical explanation of MaxEnt for ecologists. Diversity and Distributions, 17 (1): 43-57. https://doi.org/10.1111/j.1472-4642.2010.00725.x

FAHRIG, L., 2003. Effects of habitat fragmentation on biodiversity. Annual Review of Ecology, Evolution, and Systematics, 34: 487-515. https://doi.org/10.1146/ annurev.ecolsys.34.011802.132419

Gardner, A.S., Maclean, I.M.D., Gaston, K.J., 2019. Climatic predictors of species distributions neglect biophysiologically meaningful variables. Diversity and Distributions, 25: 1318-1333. https://doi.org/10.1111/ ddi.12939

Godet, L., JAFFré, M., Devictor, V., 2011. Waders in winter: long-term changes of migratory bird assemblages facing climate change. Biology Letters, 7 (5): 714-717. https:// doi.org/10.1098/rsbl.2011.0152

Grimm, N.B., Chapin, F.S., Bierwagen, B., Gonzalez, P., Groffman, P.M., Luo, Y., Melton, F., Nadelhoffer, K., Pairis, A., Raymond, P.A., Schimel, J., Williamson, C.E., 2013. The impacts of climate change on ecosystem structure and function. Frontiers in Ecology and the Environment, 11 (9): 474-482. https://doi. org/10.1890/120282

HalupKa, L., HalupKa, K., 2017. The effect of climate change on the duration of avian breeding seasons: a metaanalysis. Proceedings of the Royal Society B: Biological Sciences, 284 (1867): 20171710. https://doi.org/10.1098/ rspb.2017.1710

Heikinheimo, M., LapPalainen, H., 1997. Dependence of the flower budburst of some plant taxa in Finland on effective temperature sum: some implications for climate warming. Annales Botanici Fennici, 34: 229-243.

Huisman, J., OlfF, H., Fresco, L.F.M., 1993. A hierarchical set of models for species response analysis. Journal of Vegetation Science, 4 (1): 37-46. https://doi. org/10.2307/3235732

Jansen, F., 2013. Hierarchical species response curves in package eHOF. 9 p. [cit. 2020-10-23]. ftp://mirror.hmdc. harvard.edu/mirrors/cran.r-project.org/web/packages/ eHOF/vignettes/eHOF.pdf

Jansen, F., Oksanen, J., 2013. How to model species responses along ecological gradients - Huisman-OlffFresco models revisited. Journal of Vegetation Science, 24 (6): 1108-1117. https://doi.org/10.1111/jvs. 12050

Jetz, W., Wilcove, D.S., Dobson, A.P., 2007. Projected impacts of climate and land-use change on the global diversity of birds. PLoS Biology, 5 (6): e157. https://doi. org/10.1371/journal.pbio.0050157

Kampichler, C., van Turnhout, C.A.M., Devictor, V., van DER JEUGD, H.P., 2012. Large-scale changes in community composition: determining land use and climate change signals. PLoS ONE, 7 (4). https://doi.org/10.1371/journal. pone.0035272

Konapala, G., Mishra, A.K., Wada, Y., Mann, M.E., 2020. Climate change will affect global water availability through compounding changes in seasonal precipitation and evaporation. Nature Communications, 11 (1): 3044. https://doi.org/10.1038/s41467-020-16757-w

KoRŇAn, M., ADAmík, P., 2014. Structure of the breeding bird assemblage of a natural beech-spruce forest in the Šútovská dolina National Nature Reserve, the Malá Fatra Mts. Ekológia, Bratislava: 33 (2): 138-150. https://doi. org/10.2478/eko-2014-0014

Krosby, M., Wilsey, C.B., McGuire, J.L., Duggan, J.M., Nogeire, T.M., Heinrichs, J.A., Tewksbury, J.J., LAWLER, J.J., 2015. Climate-induced range overlap among closely related species. Nature Climate Change, 5 (9): 883-886. https://doi.org/10.1038/nclimate2699

Kunah, O.M., PaKhomov, O.Y., Zymaroieva, A.A., DemchuK, N.I., SKuPSKYI, R.M., BeZuhla, L.S., VLADYKA, Y.P., 2018. Agroeconomic and agroecological aspects of spatial variation of rye (Secale cereale) yields within Polesia and the Forest-Steppe zone of Ukraine: the usage of geographically weighted principal components analysis. Biosystems Diversity, 26 (4): 276-285. https:// doi.org/10.15421/011842

Kunah, O.M., Zelenko, Y.V., FedushKo, M.P., BABChenKo, A.V., SirovatKo, V.O., Zhukov, O.V., 2019. The temporal dynamics of readily available soil moisture for plants in the technosols of the Nikopol Manganese Ore Basin. Biosystems Diversity, 27 (2): 156-162. https://doi. org/10.15421/011921

Lee, W.H., Abdullah, S.A., Nor, S.B.M., 2019. Land use and landscape pattern changes on the inside and outside of protected areas in urbanizing Selangor State, Peninsular Malaysia. Journal of Landscape Ecology, 12 (2): 41-63. https://doi.org/10.2478/jlecol-2019-0009

Legendre, P., Birks, H.J.B., 2012. From classical to canonical ordination. In Birks, H. J. B. , LotTer, A. F., JugGins, S., Smol, J.P. (eds). Tracking environmental change using lake sediments: data handling and numerical techniques. Dordrecht: Springer, p. 201-248.

Legendre, P., GallaGHer, E.D., 2001. Ecologically meaningful transformations for ordination of species data. Oecologia, 129 (2): 271-280. https://doi.org/10.1007/ s004420100716

Luoto, M., VirkKala, R., Heikkinen, R.K., 2007. The role of land cover in bioclimatic models depends on spatial resolution. Global Ecology and Biogeography, 16 (1): 34-42. https://doi.org/10.1111/j.1466-8238.2006.00262.x

Mäntylä, E., Klemola, T., LaAksonen, T., 2011. Birds help plants: a meta-analysis of top-down trophic cascades caused by avian predators. Oecologia, 165 (1): 143-151. https://doi.org/10.1007/s00442-010-1774-2

MarcuzzI, G., 1979. The steppe. In European ecosystems. Biogeographica, 15. Dordrecht: Springer Netherlands, p. 289-342. https://doi.org/10.1007/978-94-009-9616$8 \_5$

Martin, T.E., Maron, J.L., 2012. Climate impacts on bird and plant communities from altered animal-plant interactions. Nature Climate Change, 2 (3): 195-200. https://doi.org/10.1038/nclimate1348 
Matthews, W.J., Marsh-Matthews, E., Cashner, R.C., GELwICK, F., 2013. Disturbance and trajectory of change in a stream fish community over four decades. Oecologia, 173 (3): 955-969. https://doi.org/10.1007/s00442-0132646-3

Mayfield, A.B., Chan, P.-H., Putnam, H.M., Chen, C.-S., FAN, T.-Y., 2012. The effects of a variable temperature regime on the physiology of the reef-building coral Seriatopora hystrix: results from a laboratory-based reciprocal transplant. Journal of Experimental Biology, 215 (23): 4183-4195. https://doi.org/10.1242/jeb.071688

Merow, C., Smith, M.J., Edwards, T.C., Guisan, A., McMahon, S.M., Normand, S., Thuiller, W., WÜest, R.O., Zimmermann, N.E., Elith, J., 2014. What do we gain from simplicity versus complexity in species distribution models? Ecography, 37 (12): 1267-1281. https://doi.org/10.1111/ecog.00845

MetZ, J., TielböRger, K., 2016. Spatial and temporal aridity gradients provide poor proxies for plantplant interactions under climate change: a large-scale experiment. Functional Ecology, 30 (1): 20-29. https:// doi.org/10.1111/1365-2435.12599

Michaelis, J., Diekmann, M.R., 2017. Biased niches - species response curves and niche attributes from Huisman-OlffFresco models change with differing species prevalence and frequency. PLoS ONE, 12 (8): 1-16. https://doi. org/10.1371/journal.pone.0183152

MiLlER, W., 2008. The hierarchical structure of ecosystems: connections to evolution. Evolution: Education and Outreach, 1 (1): 16-24. https://doi.org/10.1007/s12052007-0016-5

Mucina, L., 2019. Biome: evolution of a crucial ecological and biogeographical concept. New Phytologist, 222 (1): 97-114. https://doi.org/10.1111/nph.15609

Murphy, G.E.P., RomanuK, T.N., Worm, B., 2020. Cascading effects of climate change on plankton community structure. Ecology and Evolution, 10 (4): 2170-2181. https://doi.org/10.1002/ece3.6055

Novikov, G.A., 1953. Polevye issledovaniya po ekologii nazemnykh pozvonochnykh [Field studies on the ecology of terrestrial vertebrates]. Moscow: Izd. AN SSSR.

O'Connor, R.J., 1988. Multivariate analysis of ecological communities. Trends in Ecology \& Evolution, 3 (5): 121. https://doi.org/10.1016/0169-5347(88)90124-3

Oedekoven, C.S., Elston, D.A., Harrison, P.J., Brewer, M.J., Buckland, S.T., Johnston, A., Pearce-Higgins, J.W., 2017. Attributing changes in the distribution of species abundance to weather variables using the example of British breeding birds. Methods in Ecology and Evolution, 8 (12): 1690-1702. https://doi. org/10.1111/2041-210X.12811

Oksanen, J., 2012. Constrained ordination: tutorial with $R$ and vegan preliminaries: inspecting data. $R$ - Package Vegan. 9 p. [cit. 2020-11-03]. https://www.mooreecology. com/uploads/2/4/2/1/24213970/constrained_ordination. pdf

Pakhomov, O.Y., Kunakh, O.M., Babchenko, A.V., Fedushko, M.P., Demchuk, N.I., Bezuhla, L.S., TKachenko, O.S., 2019. Temperature effect on the temporal dynamic of terrestrial invertebrates in technosols formed after reclamation at a post-mining site in Ukrainian steppe drylands. Biosystems Diversity, 27 (4): 322-328. https://doi.org/10.15421/011942

Parmesan, C., 2006. December ecological and evolutionary responses to recent climate change. Annual Review of Ecology, Evolution, and Systematics, 37: 637-669. https:// doi.org/10.1146/annurev.ecolsys.37.091305.110100

Parmesan, C., Yohe, G., 2003. A globally coherent fingerprint of climate change impacts across natural systems. Nature, 421 (6918): 37-42. https://doi.org/10.1038/nature01286

Pautasso, M., 2012. Observed impacts of climate change on terrestrial birds in Europe: an overview. Italian Journal of Zoology, 79 (2): 296-314. https://doi.org/10.1080/11250 003.2011.627381

Pearson, R.G., Dawson, T.P., 2003. Predicting the impacts of climate change on the distribution of species: are bioclimate envelope models useful? Global Ecology and Biogeography, 12 (5): 361-371. https://doi.org/10.1046/ j.1466-822X.2003.00042.x

PERrins, C.M., 2008. The timing of birds' breeding seasons. Ibis, 112 (2): 242-255. https://doi.org/10.1111/j.1474919X.1970.tb00096.x

Piedallu, C., Gégout, J.-C., Lebourgeois, F., Seynave, I., 2016. Soil aeration, water deficit, nitrogen availability, acidity and temperature all contribute to shaping tree species distribution in temperate forests. Journal of Vegetation Science, 27 (2): 387-399. https://doi. org $/ 10.1111 /$ jvs. 12370

PIMm, S.L., 2009. Climate disruption and biodiversity. Current Biology, 19 (14): R595-R601. https://doi.org/10.1016/j. cub.2009.05.055

Pulliam, H.R., 2000. On the relationship between niche and distribution. Ecology Letters, 3 (4): 349-361. https://doi. org/10.1046/j.1461-0248.2000.00143.x

R CORE TEAM, 2020. R: a language and environment for statistical computing. Vienna, Austria: R Foundation for Statistical Computing. [cit. 2021-05-11]. https://www.rproject.org/

Reif, J., TelenskÝ, T., ŠŤastnÝ, K., BejČEK, V., KlvaŇa, P., 2010. Relationships between winter temperature and breeding bird abundance on community level: importance of interspecific differences in diet. Folia Zoologica, 59 (4): 313-322. https://doi.org/10.25225/fozo.v59.i4.a7.2010

Roth, T., Plattner, M., Amrhein, V., 2014. Plants, birds and butterflies: short-term responses of species communities to climate warming vary by taxon and with altitude. PLoS ONE, 9 (1): e82490. https://doi.org/10.1371/journal. pone. 0082490

Sexton, J.P., McIntyre, P.J., Angert, A.L., Rice, K.J., 2009. Evolution and ecology of species range limits. Annual Review of Ecology, Evolution, and Systematics, 40 (1): 415-436. https://doi.org/10.1146/annurev. ecolsys. 110308.120317

SHELFORD, V.E., 1931. Some concepts of bioecology. Ecology, 12 (3): 455-467. https://doi.org/10.2307/1928991

Shrivastava, P., Kumar, R., 2015. Soil salinity: a serious environmental issue and plant growth promoting bacteria as one of the tools for its alleviation. Saudi Journal of Biological Sciences, 22 (2): 123-131. https://doi. org/10.1016/j.sjbs.2014.12.001

Smith, R.K., Pullin, A.S., Stewart, G.B., Sutherland, W.J., 2010. Effectiveness of predator removal for enhancing 
bird populations. Conservation Biology, 24 (3): 820-829. https://doi.org/10.1111/j.1523-1739.2009.01421.x

TeixeIra, J., Pereira, L., 1992. ISAREG, an irrigation scheduling model. ICID Bulletin, 41 (2): 29-48.

Ter BraAk, C.J.F., Prentice, I.C., 1988. A theory of gradient analysis. Advances in Ecological Research, 18(C): 271317. https://doi.org/10.1016/S0065-2504(08)60183-X

Ter Braak, C.J.F., Šmilauer, P., 2015. Topics in constrained and unconstrained ordination. Plant Ecology, 216 (5): 683-696. https://doi.org/10.1007/s11258-014-0356-5

Thuiller, W., Araújo, M.B., Lavorel, S., 2004. Do we need land-cover data to model species distributions in Europe? Journal of Biogeography, 31 (3): 353-361. https://doi. org/10.1046/j.0305-0270.2003.00991.x

Thum, T., Aalto, T., Laurila, T., Aurela, M., Hatakka, J., Lindroth, A., Vesala, T., 2009. Spring initiation and autumn cessation of boreal coniferous forest $\mathrm{CO}_{2}$ exchange assessed by meteorological and biological variables. Tellus B: Chemical and Physical Meteorology, 61 (5): 701-717. https://doi.org/10.1111/j.16000889.2009.00441.x

Titeux, N., Maes, D., Van Daele, T., Onkelinx, T., Heikkinen, R.K., Romo, H., García-Barros, E., Munguira, M.L., Thuiller, W., van SwaAy, C.A.M., Schweiger, O., Settele, J., Harpke, A., Wiemers, M., Brotons, L., Luoto, M., 2017. The need for largescale distribution data to estimate regional changes in species richness under future climate change. Diversity and Distributions, 23 (12): 1393-1407. https://doi. org/10.1111/ddi.12634

Trautmann, S., 2018. Climate change impacts on bird species. In Tietze, D. (ed.). Bird species. Fascinating life sciences. Cham: Springer, p. 217-234. https://doi. org/10.1007/978-3-319-91689-7_12

Triviño, M., Thuiller, W., CabeZa, M., Hickler, T., ArAúJo, M.B., 2011. The contribution of vegetation and landscape configuration for predicting environmental change impacts on Iberian birds. PLOS ONE, 6 (12), e29373. https://doi.org/10.1371/journal.pone.0029373

VAN DEN WollenberG, A.L., 1977. Redundancy analysis an alternative for canonical correlation analysis. Psychometrika, 42 (2): 207-219. https://doi.org/10.1007/ BF02294050

VatKa, E., Orell, M., Rytkönen, S., 2011. Warming climate advances breeding and improves synchrony of food demand and food availability in a boreal passerine. Global Change Biology, 17 (9): 3002-3009. https://doi. org/10.1111/j.1365-2486.2011.02430.x

Velásquez-Tibatá, J., Salaman, P., Graham, C.H., 2013. Effects of climate change on species distribution, community structure, and conservation of birds in protected areas in Colombia. Regional Environmental Change, 13 (2): 235-248. https://doi.org/10.1007/s10113012-0329-y

ViRKKALA, R., 2016. Long-term decline of southern boreal forest birds: consequence of habitat alteration or climate change? Biodiversity and Conservation, 25 (1): 151-167. https://doi.org/10.1007/s10531-015-1043-0

Vorovka, V.P., Demchenko, V.O., 2019. Hydroecological problems of the Molochniy Liman in connection with the instability of its communication with the Azov Sea. Visnyk of V. N. Karazin Kharkiv National University. Series "Ecology," (21): 23-33. https://doi.org/10.26565/19924259-2019-21-02

Walther, G.-R., Roques, A., Hulme, P.E., Sykes, M.T., Pyšek, P., KÜHN, I., Zobel, M., BACheR, S., BOtTA-DukÁT, Z., Bugmann, H., Czúcz, B., Dauber, J., Hickler, T., Jarosík, V., Kenis, M., Klotz, S., Minchin, D., Moora, M., Nentwig, W., Ott, J., Panov, V.E., Reineking, B., Robinet, C., Semenchenko, V., Solarz, W., Thuiller, W., Vilà, M., Vohland, K., Settele, J., 2009. Alien species in a warmer world: risks and opportunities. Trends in Ecology \& Evolution, 24 (12): 686-693. https://doi. org/10.1016/j.tree.2009.06.008

Watts, H.E., Jimenez, D., Pacheco, V., Vilgalys, T.P., 2018. Effects of temperature on the timing of breeding and molt transitions in house finches. The Journal of Experimental Biology, 221 (18): jeb185058. https://doi.org/10.1242/ jeb. 185058

Xu, Z., Hou, Y., Zhang, L., Liu, T., Zhou, G., 2016. Ecosystem responses to warming and watering in typical and desert steppes. Scientific Reports, 6 (1): 34801. https://doi.org/10.1038/srep34801

Zhang, J., Qian, H., Girardello, M., Pellissier, V., Nielsen, S.E., Svenning, J.C., 2018. Trophic interactions among vertebrate guilds and plants shape global patterns in species diversity. Proceedings of the Royal Society B: Biological Sciences, 285 (1883). https://doi.org/10.1098/ rspb.2018.0949

Zhou, Y.-Z., JiA, G.-S., 2016. Precipitation as a control of vegetation phenology for temperate steppes in China. Atmospheric and Oceanic Science Letters, 9 (3): 162168. https://doi.org/10.1080/16742834.2016.1165594

Zimaroeva, A.A., Zhukov, O.V., Ponomarenko, O.L., 2016. Determining spatial parameters of the ecological niche of Parus major (Passeriformes, Paridae) on the base of remote sensing data. Vestnik Zoologii, 50 (3): 251-258. https://doi.org/10.1515/vzoo-2016-0029

Received December 19, 2020 Accepted May 4, 2021 